\title{
O SUPREMO TRIBUNAL FEDERAL E O CONTROLE DOS PROCESSOS DE EXTRADIÇÃO
}

Gleisse Ribeiro

\section{RESUMO}

O presente trabalho tem como objeto de estudo o instituto da extradição, um instrumento de cooperação processual internacional que retira um estrangeiro de determinado território e entrega-o a outro soberano, permitindo, assim, o julgamento de pessoas que cometeram ilícitos e deslocaram-se a outros países para fugir de julgamento ou condenação. O estudo versará sobre o conceito de extradição, seus princípios, a evolução histórica e apresentará o processo extradicional e o Supremo Tribunal Federal.

Palavras-chave: extradição; Supremo Tribunal Federal (STF); processo extradicional.

\section{The Supreme Federal Court and the control of the extradition processes}

\begin{abstract}
The objective of the present work is to study the institute of the extradition that is an international procedural instrument of cooperation that removes foreigners a certain territory and gives their to other sovereign allowing like this the judgement of people that committed illicit and they moved for other countries to shine of judgement or condemnation. The study will turn on extradition concept, their principles, historical evolution the extradition institute and it will approach the theme of the process extradicional and the Federal Supreme Court.
\end{abstract}

Keywords: extradition; Supreme Federal Court; extradition processes 


\section{Introdução}

Quais são os pressupostos nos processos de extradição no Brasil? Qual é o papel e o controle do STF nos processos extradicionais? A extradição é um dos institutos jurídicos que permite a retirada do estrangeiro de determinado território. Cahali (1983, p. 295) conceitua extradição como o "ato pelo qual um Estado entrega um indivíduo acusado ou reconhecido como culpado de uma infração cometida fora de seu território, a outro Estado que o reclama e que é competente para julgá-lo e puni-lo”. O estrangeiro, desde os tempos mais remotos, é considerado como sujeito de direito: "Se o estrangeiro peregrinar na vossa terra, não o oprimireis. Como o natural entre vós será o estrangeiro que peregrina convosco. Amálo-eis como a vós mesmos, pois fostes estrangeiros na terra do Egito”1.

O direito de ir e vir é um direito fundamental garantido pela Constituição no artigo 5 $\mathrm{XV}$ : “é livre a locomoção no território nacional em tempo de paz, podendo qualquer pessoa, nos termos da lei, nele entrar, permanecer ou dele sair com seus bens”. O direito de locomover-se livremente deu origem aos movimentos migratórios que têm contribuído para a evolução da humanidade. Pagden (2002, p. 22) explica que a migração contribui para a evolução do homem porque os povos, na tentativa de fugir de perseguições, da pobreza, da falta de perspectivas econômicas, migram para outras regiões, cruzam oceanos e continentes e passam a conviver com gente alheia.

Cavarzere (2001, p. 12) ressalta que a convivência entre povos diferentes é um estímulo à invenção e à imitação, tendo em vista que as áreas onde ocorreram maiores movimentos de migração são regiões mais desenvolvidas. Exemplo dessa afirmação é a região Norte do Brasil que, por ser de difícil acesso, é menos desenvolvida se comparada com a região Sudeste.

A origem dos movimentos migratórios confunde-se com a história dos impérios que se inicia na Grécia antiga. O primeiro e grandioso império construído foi o de Alexandre, o Grande. Pagden (2002, p. 35) descreve que “o império de Alexandre foi o mais extenso da Antiguidade”, e estendeu-se de 336 a 323 a. C. A sucessora do império de Alexandre foi Roma, que surgiu no século VII a C. e seguiu, da mesma forma, os processos de conquista. Por meio das grandes navegações, foi possível a descoberta de novas terras, o que

\footnotetext{
${ }^{1}$ Levítico 19,33.
} 
proporcionou o crescente número dos movimentos migratórios. Após o descobrimento do Brasil, Mialhe (2003, p 210) divide os movimentos migratórios internacionais em quatro períodos: $1^{\circ}$ período, abrangendo o ano de 1500 a 1800; $2^{\circ}$ período, o século XIX; $3^{\circ}$ período, do ano de 1900 a 1915; $4^{\circ}$ período, de 1950 aos dias atuais.

No primeiro período, o modelo de migração mundial era dominado pela Europa e derivava do processo de colonização e crescimento econômico baseado no mercantilismo. No segundo período, o processo migratório foi marcado pelos movimentos de independência política de várias colônias e de industrialização dos novos países. No terceiro período, houve a massiva transferência de pessoas de países industrializados da Europa para as várias colônias e ex-colônias. No período entre guerras até antes de 1950, vários e importantes países receptores de estrangeiros aprovaram leis restritivas de imigração e, no início da grande depressão em 1929, houve a paralisação da migração internacional. No quarto e último período, ao contrário dos anteriores, a imigração tornou-se um fenômeno global com a multiplicação do número e da variedade de imigrantes e de emigrantes.

Mialhe (2003, p. 217) comenta que, com o fim da Segunda Guerra Mundial, ocorreu mudança considerável na estrutura e na composição das migrações internacionais. O massivo crescimento transatlântico, causado pela industrialização da Europa e pelo rápido desenvolvimento do Novo Mundo, deu lugar a uma forma diversa de imigração: de países do Terceiro Mundo (do sul) para os países desenvolvidos (do norte); deslocamento do Pacífico Sul para alguns ricos produtores de petróleo no Oriente Médio.

Com o decorrer dos anos, a entrada do estrangeiro em determinado território tem sido limitada. Milesi (2004, p. 3) afirma que, principalmente com os processos de globalização, os países têm estabelecido, em suas políticas elitistas, quotas de imigração, delimitando o número máximo de entrada de estrangeiros. As quotas são limitadas por nacionalidade ou por região continental, e os critérios de seleção dos imigrantes beneficiam apenas um número reduzido de estrangeiros que, em geral, já pertencem a categorias diferenciadas ou marginalizadas em seu país de origem.

Verifica-se que o estrangeiro, ao longo dos anos, tem a prerrogativa do direito à liberdade de locomoção e que, cada vez mais, os países têm estabelecido critérios para a entrada de um estrangeiro em seu território. Esse tem sido um tema constante na agenda da 
comunidade internacional. A justificativa para tal controle é a questão do terrorismo que tanto tem preocupado os governos, principalmente o dos Estados Unidos, depois do ataque terrorista de 11 de setembro de 2001.

Da mesma forma que o estrangeiro segue regras para adentrar em um país, também há critérios para sua retirada de determinado país. Dolinger, (2003, p. 208) afirma que a condição jurídica de um estrangeiro em determinado território segue três princípios: solidariedade internacional, direito internacional e o respeito à soberania dos países. São três os institutos positivados pelo Direito brasileiro para a saída compulsória do estrangeiro: deportação, expulsão e extradição.

A deportação (Lei 6.815/80, artigos de 57 a 64) origina-se na entrada ou na estada irregular do estrangeiro no país. Dolinger (2003, p. 245) conceitua deportação como “o processo de devolução de estrangeiro que aqui chega ou permanece irregularmente, para o país de sua nacionalidade ou de sua procedência”. Sobre a expulsão, regulamentada pela Lei 6.815/80, nos artigos de 65 a 75, Dolinger (2003, p. 249) salienta que “é o processo pelo qual um país retira do seu território estrangeiro residente, em razão de crime ali praticado ou de comportamento nocivo aos interesses nacionais”. A expulsão, no artigo 66, é um ato de competência exclusiva do Presidente da República, a quem cabe resolver sobre a sua conveniência. Praticamente, não tem qualquer regulamentação internacional e, em conseqüência, é um ato soberano do Estado sem maiores limitações impostas pela ordem jurídica internacional. O caso mais recente que originou um processo de expulsão, no Brasil, foi o cancelamento do visto do correspondente do jornal The New York Times em decorrência de uma matéria publicada sobre o envolvimento do presidente brasileiro, Luis Inácio Lula da Silva, com bebidas alcoólicas. Segue, abaixo, a nota expedida pelo Ministério da Justiça:

"Em face da reportagem leviana, mentirosa e ofensiva à honra do Presidente da República do Brasil, com grave prejuízo à imagem do país no exterior, publicada na edição de 9 de maio passado do jornal The New York Times, o Ministério da Justiça considera, nos termos do artigo 26 da Lei $\mathrm{n}^{\circ}$ 6.815, inconveniente a presença em território nacional do autor do referido texto. Nessas condições, determinou o cancelamento do visto temporário do sr. William Larry Rohter Junior”.2

\footnotetext{
${ }^{2}$ Ministério da Justiça, Nota Oficial em 11/05/2004.
} 
O repórter William Larry Rohter Junior não chegou a ser expulso tendo em vista a nota de retratação enviada ao governo brasileiro:

"William Larry Rohter afirmou jamais ter tido a intenção de ofender a honra do Excelentíssimo Senhor Presidente da República, a quem já pôde, até mesmo, entrevistar em algumas ocasiões e reafirma seu grande afeto pelo Brasil e seu profundo respeito às instituições democráticas brasileiras, incluindo a Presidência da República", completando que o "mal entendido" foi ampliado porque "a versão de seu texto para o português não é fidedigna". De posse da carta, o ministro Márcio Thomaz Thomaz Bastos reuniu-se com o presidente Luis Inácio Lula da Silva, que decidiu pela não expulsão do jornalista.”

Quanto ao terceiro e último instituto que permite a retirada do estrangeiro do território nacional, Dolinger (2003, p. 245) menciona que “a extradição é o processo pelo qual um Estado, atendendo ao pedido de outro, remete-lhe a pessoa processada ou reconhecida como culpada no país solicitante, por crime punido na legislação de ambos”.

Os países utilizam a extradição como meio processual internacional para permitir o julgamento das pessoas que cometeram ilícitos e deslocaram-se a outros países para fugir de julgamento e condenação. A comunidade internacional tem considerado a extradição como um dos mecanismos de cooperação internacional capaz de reprimir atividades delituosas e uma forma de inibir a atividade terrorista que tanto tem gerado ameaças à paz e à segurança internacional. Conforme estipulado no artigo 83 do Estatuto do Estrangeiro: "nenhuma extradição será concedida sem prévio pronunciamento do Plenário do Supremo Tribunal Federal sobre sua legalidade e procedência, não cabendo recurso da decisão”. Verifica-se que o processo de extradição é o instituto relacionado ao estrangeiro que maior ligado está à nossa Corte Suprema.

\section{Extradição}

\subsection{Conceito}

A extradição é o ato pelo qual um Estado entrega um indivíduo, acusado de um delito ou já condenado como criminoso, à justiça do outro, que o reclama e que é competente para julgá-lo e puni-lo ${ }^{3}$.

\footnotetext{
${ }^{3}$ ACCIOLY, 1968, p. 105.
} 
A comunidade internacional tem buscado meios que possam garantir a paz mundial e a harmonia entre os povos. Acordos de proteção e cooperação penal internacional têm sido discutidos de forma mais imperativa, principalmente depois da ação terrorista ocorrida nos Estados Unidos, em 11 de setembro de 2001. Dessa forma, o instituto da extradição está cada vez mais presente nos acordos de cooperação entre os países, tendo em vista ser esse um procedimento que possibilita ao indivíduo acusado de delito ou condenado como criminoso ser punido pelo Estado competente.

Os autores abaixo exprimem, de forma abrangente, conceitos de extradição:

"a extradição é um instituto de cooperação internacional na luta contra o crime. Interessa tanto ao Estado que o requisita quanto ao Estado que entrega os criminosos. Esse interesse recíproco que têm todas as nações em evitar que os criminosos se subtraiam à merecida punição, procurando refúgio em outro território, não atenta contra o exercício de sua soberania.”4

Francisco Rezek afirma que:

"extradição é a entrega, por um Estado a outro e a pedido deste, de indivíduo que, em seu território, deve responder a processo penal ou cumprir pena, cuidando-se de uma relação executiva, com envolvimento judiciário de ambos os lados: o governo requerente da extradição só toma essa iniciativa em razão da existência de processo penal - findo ou em curso - ante sua Justiça; e o governo do Estado requerido [...] não goza, em geral, de uma prerrogativa de decidir sobre o atendimento do pedido senão depois de um pronunciamento da Justiça local." ${ }^{5}$

Cahali (1983, p. 296) comenta que, no passado, alguns estudiosos, baseados no princípio da proteção da liberdade humana, contestavam a legitimidade do instituto da extradição, cuja justificativa é citada a seguir:

a) a extradição é um ato de justiça na medida em que nenhum indivíduo deve ter a faculdade de eximir-se das conseqüências das infrações cometidas;

b) a segurança do Estado está ligada à colaboração prestada na punição dos malfeitores;

c) para que o indivíduo tenha o direito à liberdade respeitado, é necessário que as suas ações não contrariem outro direito.

\footnotetext{
${ }^{4}$ CARNEIRO, 2002, p. 18.

${ }^{5}$ VELLOSO, 2003, P. 117.
} 


\subsection{Princípios que regem a extradição}

O Estatuto do Estrangeiro dispõe, no artigo 76, o fundamento que rege o pedido de extradição: “A extradição poderá ser concedida quando o governo requerente se

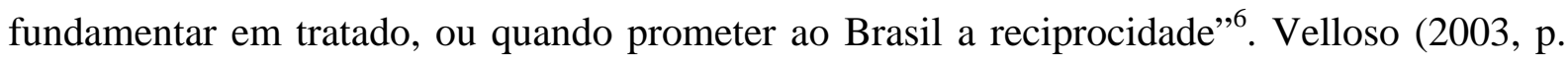
117) afirma que, quando um pedido de extradição se fundamenta em promessa de reciprocidade, poderá ser recusado pelo governo requerido. No entanto, a recusa não poderá ocorrer se o pedido de extradição for fundamentado por meio de um tratado, o qual constitui lei entre as partes envolvidas e não depende da reciprocidade, da relação de confiança e do empenho da palavra de um Estado para com o outro. Além dos fundamentos, o instituto da extradição, conforme afirma Cahali (1983 p. 303-304), possui os seguintes princípios:

a) princípio da especialidade: concedida a extradição, o Estado requerente não poderá julgar o extraditando por delito diferente daquele que fundamentou seu pedido de extradição. Conforme rege o Estatuto do Estrangeiro, no artigo 91: "não será efetivada a entrega sem que o Estado requerente assuma o compromisso: I - de não ser o extraditando preso nem processado por fatos anteriores ao pedido”.

b) Princípio da Identidade ou dupla incriminação: não se concederá a extradição quando o fato que motivar o pedido não for considerado crime no país de refúgio. Conforme rege o Estatuto do Estrangeiro, no artigo 77: "não se concederá a extradição quando: II - fato que motivar o pedido não for considerado crime no Brasil ou no Estado requerente”

Alguns autores inserem o pressuposto Nom bis in idem (evitar que o indivíduo seja punido duas vezes pelo mesmo crime) no rol dos princípios do processo extradicional. O pressuposto foi consagrado no Código Bustamante, artigo 358. Como explica Fraga (1985, p. 301), “se o agente já está aqui, sendo processado, ou se já foi condenado ou absolvido, não se justifica entregá-lo a outro Estado”.

\subsection{Evolução histórica do instituto da extradição}

O instituto da extradição nem sempre teve as mesmas características tal como na atualidade. Ao longo dos séculos, os procedimentos e as razões que fundamentavam um

\footnotetext{
${ }^{6}$ Lei 6.815 de 1980.
} 
soberano a entregar um indivíduo a outro soberano foram modificadas segundo as circunstâncias e as necessidades de determinada época.

Acquarone (2003, p. 33) comenta que a extradição só adquiriu o aspecto de mecanismo possibilitador de combate ao crime a partir do final do século XVIII, quando houve maior mobilidade dos salteadores, desertores, assassinos e ladrões. Pela maior facilidade de locomoção dos criminosos, os soberanos necessitaram, então, de um mecanismo que possibilitasse a captura dos fugitivos. Carneiro (2002, p. 23-34) salienta que, para maior compreensão da evolução histórica da extradição, é necessário dividi-la em três períodos: $1^{0}$ período, da Antiguidade ao século XVII; $2^{\circ}$ período, dos séculos XVIII ao XIX; $3^{\circ}$ período, do final do século XIX aos dias atuais.

a) $1^{\circ}$ período, da Antiguidade ao século XVII: um exemplo do instituto da extradição que data dessa época é a entrega de Sansão realizada pelos israelitas a pedido dos filisteus. Carneiro (2002, p. 23) cita que “o primeiro documento conhecido que continha algumas das características da extradição ficou conhecido como o Tratado de Paz entre o Faraó Ramsés II e o Soberano Hitita, príncipe Hattisulo, celebrado no ano de 1280 a. C”. O autor comenta, ainda, que data dessa época um tratado internacional celebrado no ano de 1376 entre o Rei Carlos V da França e o Conde de Sabóia, considerado como o instrumento que mais se aproxima dos procedimentos da extradição, tal como o instituto vigora na atualidade.

b) $2^{\circ}$ período, do século XVIII ao século XIX: alguns doutrinadores comentam que é nesse período que a extradição se consolida como instrumento jurídico. Carneiro (2002, p. 26) ressalta que isso ocorre por meio do tratado celebrado entre a França e os Países Baixos, onde se estabeleceu a entrega de criminosos e foram enumerados os crimes passíveis de extradição. O procedimento extradicional, embora de forma precária, inicia-se no Brasil com os acordos estabelecidos com Alemanha, França, Inglaterra, Portugal e Rússia, que previam serem passíveis de extradição os indivíduos que cometessem crimes de rebelião do vassalo contra o seu senhor, a deslealdade, a traição, a produção de dinheiro falso. Acquarone (2003, p. 34) comenta que 92 tratados que abordam temas relacionados à extradição datam dessa época. Carneiro (2002, p. 27-29) cita que, no ano de 1808, com a chegada da Corte Portuguesa ao Brasil e a abertura dos portos brasileiros ao comércio, a política governamental brasileira favoreceu a entrada e a estada de estrangeiros no solo brasileiro. Em decorrência disso, os pedidos de extradição aumentaram significativamente, o que obrigou o governo brasileiro a 
estabelecer normas que regulamentassem o processo extradicional. Dessa forma, em 1847, foi expedida pelo Ministério dos Negócios Estrangeiros a circular que constituiu o primeiro documento classificando em que ocasião se daria o deferimento dos pedidos de extradição como descrito a seguir:

\begin{abstract}
"Quando os crimes pelos quais se reclamar a extradição tiverem sido cometidos no território do Governo reclamante, e este oferecer ou se prestar à reciprocidade; quando pela gravidade e habitual freqüência forem capazes de pôr em risco a moral e a segurança dos Povos, tais como os de roubo, assassinato, moeda falsa, falsificações e alguns outros; quando estiverem provados de maneira que a leis do Brasil justifiquem a prisão e acusação, como se o crime tivesse sido nele cometido; quando o suspeito ou criminoso for reclamado pelo Ministro da Nação em que tiver lugar o delito; se o mesmo indivíduo for criminoso em mais de um Estado e for reclamada sua entrega por mais de um Governo, a entrega deverá ser feita ao Governo em cujo território tiver sido cometido o delito mais grave".7
\end{abstract}

c) $3^{\circ}$ período: do final do século XIX aos dias atuais: é nesse período que a extradição adquire características definitivas e consolida-se por meio de convenções, como o Código Bustamante, que, nos artigos de 344 a 381, normatiza o instituto extradicional. A extradição no Brasil, atualmente, é regulamentada pelos seguintes instrumentos legais:

i) Constituição Federal de 1988 - artigo 5², LI e LII; artigo 12; artigo 102, I, g;

ii) Lei 6.815 de 1980 (Estatuto do Estrangeiro) - artigos 76 a 94;

iii) Regimento Interno do Supremo Tribunal Federal - artigos 204 a 214: a quem compete processar e julgar, originariamente, os pedidos de extradição.

Ao longo dos três períodos, Mello (2002, p. 982) afirma que a extradição passou por três fases: i) contratual: a extradição era concedida apenas por meio de tratado; ii) legislativa: quando os Estados passam a promulgar leis de extradição; iii) regulamentação internacional, que ainda não vigora de modo geral. A dúvida suscitada entre os doutrinadores é se o Tribunal Penal Internacional (TPI) ${ }^{8}$ havia regulamentado a extradição na esfera multilateral, tendo em vista que estabeleceu normas para a entrega de pessoas ao Tribunal:

\footnotetext{
${ }^{7}$ CARNEIRO, 2002 p. 28.

${ }^{8}$ Em julho de 1998, durante a realização da Conferência Diplomática de Plenipotenciários das Nações Unidas, foi aprovado o Estatuto do Tribunal Penal Internacional, também conhecido como Estatuto de Roma, que estabelece as condições de funcionamento da nova jurisdição criminal. O Tribunal Penal Internacional tem caráter permanente e independente no âmbito do sistema das Nações Unidas e com jurisdição sobre os crimes contra a humanidade e de genocídio que afetam a comunidade internacional. No Brasil, o Estatuto foi aprovado por meio do Decreto legislativo $\mathrm{n}^{\circ} 112$ de 06/06/02 e promulgado pelo Decreto 4.388 de 25/09/02. Fonte: http://www.jusnavegandi.com.br
} 
“Artigo 89

Entrega de Pessoas ao Tribunal

1. O Tribunal poderá dirigir um pedido de detenção e entrega de uma pessoa, instruído com os documentos comprovativos referidos no artigo 91, a qualquer Estado em cujo território essa pessoa se possa encontrar, e solicitar a cooperação desse Estado na detenção e entrega da pessoa em causa. Os Estados Partes darão satisfação aos pedidos de detenção e de entrega em conformidade com o presente Capítulo e com os procedimentos previstos nos respectivos direitos internos.”

A maioria dos doutrinadores tem optado pela argumentação de que o TPI não regulamentou o processo extradicional no âmbito internacional porque a extradição e a entrega, regidas pelo Tribunal, são instrumentos jurídicos diferentes:

\begin{abstract}
“A extradição requer o auxílio mútuo entre dois países onde um confia ao outro uma pessoa; na entrega, o Estado estaria sujeitando-se a uma vontade judicial proveniente de uma corte internacional supra nacional e, portanto, acima das soberanias estatais da qual ele mesmo é membro. Em outras palavras a extradição configura uma cooperação horizontal, visto que os entes de Direito Internacional estão em mesmo plano hierárquico e entrega é uma forma de cooperação vertical, onde os sujeitos de Direito Internacional estão em níveis hierárquicos diferentes”9.
\end{abstract}

\title{
3. Processo extradicional e o Supremo Tribunal Federal
}

Conforme citado anteriormente, o Supremo Tribunal Federal (STF) é a autoridade competente a pronunciar sobre os pedidos de extradição. Nossa Corte Suprema foi instalada em caráter provisório, na Casa do Ilustríssimo Senado da Câmara, no Rio de Janeiro, em 29 de janeiro de 1829, sob a presidência de José Albano Fragoso. O Ministro Celso de Mello (2004), ao resumir a história do STF, disse que o órgão teve várias denominações: Casa da Suplicação do Brasil (de 10/05/1808 a 08/01/1829); Supremo Tribunal de Justiça (de 09/01/1829 a 27/02/1891) e Supremo Tribunal Federal (desde 28/02/1891). A cidade do Rio de Janeiro sediou, no período monárquico, o Supremo Tribunal de Justiça (1829/1891) e, na fase republicana, até 20/04/1960, o Supremo Tribunal Federal. Brasília passou ser a sede constitucional do Supremo Tribunal Federal desde o dia 21/4/1960, data em que se deu a instalação na nova capital da República.

Com o Brasil República, houve a necessidade de ter um tribunal ajustado à nova realidade política. Dessa forma, em 1890, foi instituído o Supremo Tribunal Federal, que teve como inspiração principal a Corte Suprema Americana. Vieira (1994, p. 72) explica que o STF foi alvo de pressões, limitações e intervenções com a “aposentadoria compulsória de

\footnotetext{
${ }^{9}$ Caletti 2003, p. 02.
} 
diversos ministros em 1931 e 1969, por não se submeterem aos regimes de poder dos anos de 1930 e 1964”. A Constituição de 1988 não modificou a estrutura do STF, houve apenas alterações quanto às atribuições de poder:

a) ampliação dos agentes legitimados a propor a ação direta de inconstitucionalidade;

b) criação de instrumentos para garantir a eficácia dos direitos constitucionais que dependam de regulamentação;

c) ampliação das hipóteses de controle material da constitucionalidade de emendas à constituição;

d) permanência do controle difuso da constitucionalidade, cuja capacidade para deixar de aplicar uma lei entendida como inconstitucional, num caso concreto, é entregue a todos os órgãos do Poder Judiciário; esse controle difuso tem o STF como a última instância.

\subsection{Processo extradicional}

O processo extradicional, conforme salienta Meira (2003, p. 102), segue três fases principais:

a) administrativa: compreende o recebimento do pedido até o envio dos autos para o STF;

b) judicial: consiste na verificação da legalidade e no julgamento do pedido;

c) entrega do extraditando

A extradição poderá ser ativa, quando solicitada pelo Brasil, ou passiva, quando requerida ao Brasil por outro Estado. No processo extradicional passivo, que é o objeto do presente trabalho, o órgão competente para receber o pedido de extradição ( $1^{\mathrm{a}}$ fase) é o Ministério das Relações Exteriores, que o encaminha ao Ministério da Justiça (MJ). Mello (2002, p. 998) afirma que o MJ, por meio do Aviso Ministerial de Solicitação de Medida da Extradição, remete a solicitação de extradição ao STF. O Supremo Tribunal Federal apreciará a legalidade do pedido ( $2^{\mathrm{a}}$ fase) sem, entretanto, apreciar o mérito, pois o julgamento do extraditando realizar-se-á no país requerente. A função do STF no processo está regulamentada nos seguintes instrumentos:

Estatuto do Estrangeiro, artigo 83: "Nenhuma extradição será concedida sem o prévio pronunciamento do Plenário do Supremo Tribunal Federal sobre sua legalidade e procedência, não cabendo recurso da decisão”.

Constituição Federal, artigo 102, I, g: "Compete ao Supremo Tribunal Federal, precipuamente, a guarda da Constituição, cabendo-lhe processar e julgar, originariamente, a extradição solicitada pr Estado estrangeiro". 
Regimento Interno do STF, artigo 207: "Não se concederá extradição sem o prévio pronunciamento do Supremo Tribunal Federal sobre a legalidade e a procedência do pedido, observada a legislação vigente”.

Adicionados aos princípios que regem os pedidos de extradição, há aspectos pertencentes à solicitação que devem ser analisados pelo STF. Os pressupostos estão regulamentados no Estatuto do Estrangeiro, nos artigos 77 e 78, descritos a seguir.

\subsubsection{Extradição de nacional}

Em alguns países, como é o caso do Brasil, a nacionalidade da pessoa pode ser empecilho à sua extradição. A nacionalidade está regulamentada como excludente à extradição no Estatuto do Estrangeiro, no artigo 77, e na Constituição Federal, artigo 5², LI:

“Art. 77. Não se concederá a extradição quando:

I - se tratar de brasileiro, salvo se a aquisição dessa nacionalidade verificar-se após o fato que motivar o pedido;

Art. $5^{\circ}$ Todos são iguais perante a lei, sem distinção de qualquer natureza, garantindo-se aos brasileiros e aos estrangeiros residentes no País a inviolabilidade do direito à vida, à liberdade, à igualdade, à segurança e à propriedade, nos termos seguintes:

LI - nenhum brasileiro será extraditado, salvo o naturalizado, em caso de crime comum, praticado antes da naturalização, ou de comprovado envolvimento em tráfico ilícito de entorpecentes e drogas afins, na forma da lei.”

É importante ressaltar que a legislação brasileira já permitiu a extradição de brasileiro nato em 1911, por meio da Lei $n^{0} 2.416$ :

“a extradição de nacionais será concedida quando, por lei ou tratado, o país requerente assegurar ao Brasil a reciprocidade de tratamento; a mesma lei consagrou também a interferência necessária do Poder Judiciário nas extradições. Somente a partir da Constituição de 16 de julho de 1934, passou-se a inadmitir a extradição de nacionais, sendo essa proibição reafirmada nas constituições posteriores. ${ }^{10,}$

No que diz respeito à extradição de brasileiro naturalizado, em caso de envolvimento com tráfico ilícito de entorpecentes e drogas afins, a jurisprudência ${ }^{11}$ do STF tem-se posicionado da seguinte forma:

"tratando-se de extradição requerida contra brasileiro naturalizado, fundada em suposta prática de tráfico ilícito de entorpecentes e drogas afins, impõe-se ao Estado requerente a comprovação do envolvimento da pessoa reclamada na

${ }^{10}$ CAHALI 1983, p. 306.

11 STF - Ext 541; Ext. 690; Ext 588 
realização do episódio delituoso. E mais: que a ressalva introduzida pela norma inscrita no inciso LI do artigo $5^{\circ}$ da Constituição institui procedimento, a ser disciplinado em lei, destinado a ensejar cognição judicial mais abrangente do conteúdo da acusação penal estrangeira, em ordem a permitir ao Supremo Tribunal Federal, na ação de extradição passiva, o exame do próprio mérito da persecutio criminis instaurada perante a autoridade do Estado requerente, certo que a simples e genérica afirmação constante de mandado judicial estrangeiro, de que existem graves indícios de culpa pertinentes ao suposto envolvimento de brasileiro naturalizado na prática do delito de tráfico de entorpecentes, não satisfaz a exigência constitucional inscrita no art. 5, LI da Carta Política”. ${ }^{12}$

O Estatuto da Igualdade de 1971, acordo existente entre Brasil e Portugal, estabelece que "portugueses e brasileiros que gozam do Estatuto da Igualdade não estão sujeitos à extradição, salvo se requerido pelo governo do Estado da nacionalidade”. Cahali (1983, p. 322) explica que “o português fica sujeito à lei penal brasileira, do mesmo modo que o nacional, não sendo passível de extradição, salvo se requerida pelo governo Portugal”.

\subsubsection{Crime com dupla tipificação de pequena gravidade e não prescrito}

A exigência da dupla tipificação é pertinente, pois a extradição é um instituto que visa à repressão da criminalidade e, para tal, é necessário que a legislação dos países envolvidos, no processo de extradição, considere o fato como crime. Além da dupla tipificação, a legislação brasileira estabelece que a infração tenha certa gravidade e que, observadas as duas legislações, o crime não esteja prescrito.

Artigo 77. Não se concederá a extradição quando:

II - o fato que motivar o pedido não for considerado crime no Brasil ou no Estado requerente;

IV - a lei brasileira impuser ao crime a pena de prisão igual ou inferior a 1 (um) ano;

VI - estiver extinta a punibilidade pela prescrição segundo a lei brasileira ou a do Estado requerente;

\subsubsection{Competência para julgar o extraditando}

Artigo 78. São condições para concessão da extradição:

I - ter sido o crime cometido no território do Estado requerente ou serem aplicáveis ao extraditando as leis penais desse Estado;

\footnotetext{
12 Jurisprudência STF, Ext 588 - Voto Ministro Celso de Mello.
} 
II - existir sentença final de privação de liberdade, ou estar a prisão do extraditando autorizada por Juiz, Tribunal ou autoridade competente do Estado requerente, salvo o disposto no artigo 82.

Artigo 77. Não se concederá a extradição quando:

III - o Brasil for competente, segundo suas leis, para julgar o crime imputado ao extraditando; V - o extraditando estiver a responder a processo ou já houver sido condenado ou absolvido no Brasil pelo mesmo fato em que se fundar o pedido;

A Corte Suprema brasileira analisa a quem compete julgar o extraditando e busca evitar que o indivíduo, envolvido no processo de extradição, seja punido duas vezes pelo mesmo crime.

\subsubsection{Delitos políticos}

Artigo 77. Não se concederá a extradição quando:

VII - o fato constituir crime político

De um modo geral, os países não concedem extradição quando o fato motivador for crime político, tendo em vista que esses crimes são ações ou omissões consideradas contrárias às Instituições dominantes. Fraga (1985, p. 302) salienta que a repressão ao crime político só interessa ao Estado onde foi cometido, é uma repressão puramente local, pois, na maioria dos casos, não ofende as instituições de outros países. Caberá, portanto, ao STF analisar se o fato motivador do pedido de extradição constitui crime político ou comum.

\subsubsection{Tribunais de Exceção}

Artigo 77. Não se concederá a extradição quando:

VIII - o extraditando houver de responder, no Estado requerente, perante Tribunal ou Juízo de exceção.

$\S 1^{\circ}$ A exceção do item VII não impedirá a extradição quando o fato constituir, principalmente, infração da lei penal comum, ou quando o crime comum, conexo ao delito político, constituir o fato principal. 
$\S 2^{\circ}$ Caberá, exclusivamente, ao Supremo Tribunal Federal, a apreciação do caráter da infração.

$\S 3^{\circ}$ O Supremo Tribunal Federal poderá deixar de considerar crimes políticos os atentados contra Chefes de Estado ou quaisquer autoridades, bem assim os atos de anarquismo, terrorismo, sabotagem, seqüestro de pessoa, ou que importem propaganda de guerra ou de processos violentos para subverter a ordem política ou social.

Os tribunais de exceção não fazem parte do Poder Judiciário dos Estados. Fraga (1985, p. 306) explica que o “Tribunal de exceção é criado para julgar, sem garantias normais, determinados crimes retirados da competência dos Tribunais comuns; é instituído por ocasião de guerra civil, revolução”. A principal justificativa para não se extraditar um indivíduo a um tribunal de exceção deve-se à não-imparcialidade nos julgamentos. A comunidade internacional avançou na questão de julgamentos que transcendem as fronteiras estatais ao instituir um Tribunal Penal Internacional. O Tribunal poderá solicitar a entrega de indivíduos que deverão ser julgados por crimes que fogem à jurisdição dos Estados. É necessário, portanto, que os países ratifiquem o Estatuto de Roma, acordo que institui o Tribunal Penal Internacional, para que o mesmo tenha legitimidade perante todos os países.

Ao STF cabe, portanto, a análise de todos os itens citados. Como exemplo, há o pedido de extradição $\mathrm{n}^{0}$ 731, solicitado pelo Governo da Itália ao Brasil: solicitação do italiano Luigi Marro para cumprir pena, relativa a cinco sentenças definitivas, de 9 anos, 3 meses e 25 dias pelos crimes de furto, roubo, calúnia, receptação e tráfico ilícito de entorpecentes. O Supremo procedeu à seguinte análise do pedido:

1) extraditando residente no Brasil desde 1985 não naturalizado, casado com brasileira, união que resultou em filho de oito anos (casamento com brasileira e filho dependente não impedem a extradição: Ext. 766);

2) quanto aos crimes de furto, roubo e calúnia, configurou-se a prescrição;

3) crime de receptação: o fato não constitui crime no direito brasileiro;

4) tráfico ilícito de entorpecentes: para o governo italiano, a sentença foi de 8 anos de reclusão e, para o governo brasileiro, de 7 anos, com direito à detração de 3 anos e 24 dias pelo tempo que cumpriu pena na Itália e o período em que esteve preso no Brasil.

Para o governo brasileiro, a extradição foi deferida, em parte, pois o extraditando foi entregue para cumprir o resíduo de pena de 3 anos, 11 meses e 6 dias de reclusão. 
Para que ocorra a análise do pedido e a extradição com o devido processo legal, a pessoa reclamada deverá ficar sob custódia do STF, e o Ministro relator expedirá o pedido de prisão preventiva do extraditando:

Estatuto do Estrangeiro Artigo 81: “Art. 81. O Ministério das Relações Exteriores remeterá o pedido ao Ministério da Justiça, que ordenará a prisão do extraditando colocando-o à disposição do Supremo Tribunal Federal”;

Estatuto do Estrangeiro Artigo 84: Efetivada a prisão do extraditando (artigo 81), o pedido será encaminhado ao Supremo Tribunal Federal.

Parágrafo único. A prisão perdurará até o julgamento final do Supremo Tribunal Federal, não sendo admitidas a liberdade vigiada, a prisão domiciliar, nem a prisão albergue.

O depoimento e a defesa dar-se-ão nos seguintes termos:

Estatuto do Estrangeiro Artigo 85: “Ao receber o pedido, o Relator designará dia e hora para o interrogatório do extraditando e, conforme o caso, dar-lhe-á curador ou advogado, se não o tiver, correndo do interrogatório o prazo de dez dias para a defesa.

$\S 1^{\circ}$ A defesa versará sobre a identidade da pessoa reclamada, defeito de forma dos documentos apresentados ou ilegalidade da extradição”.

Carneiro (2002, p. 90) ressalta que, quanto à defesa, “o extraditando poderá utilizar-se do remédio jurídico o habeas corpus e dos embargos declaratórios em extradição”. Ao ser o pedido de extradição deferido, ou seja, autorizado para que o Poder Executivo possa decidir sobre a entrega ou não do extraditando, o processo atinge a $3^{\text {a }}$ fase e finaliza-se com a entrega do extraditando, se assim o Chefe do Executivo decidir.

Decreto ${ }^{0} 86.715$ de 10/12/1981, artigo 110: “Compete ao Departamento de Polícia Federal, por determinação do Ministro da Justiça”:

I - efetivar a prisão do extraditando;

II - proceder à sua entrega ao Estado ao qual houver sido concedida a extradição.

Parágrafo único - Da entrega do extraditando será lavrado termo, com remessa de copia ao Departamento Federal de Justiça.

O STF, ao longo dos anos, tem julgado, em número crescente, mais pedidos de extradição. O gráfico abaixo mostra que, na década de noventa, o número máximo de julgamentos sobre extradição atingiu o patamar de quarenta e dois e atingiu mais que o dobro no ano de 2003, com oitenta e oito julgamentos. Uma das explicações que se pode auferir sobre o crescente número de pedidos de extradição deve-se à crescente preocupação da comunidade internacional em combater a criminalidade e pela progressiva vontade política entre os países de cooperar e possibilitar a punição de criminosos ou culpados que migram 
para outros territórios, na tentativa de ficarem impunes. O Gráfico 1 apresenta o quantitativo dos processos de extradição julgados pelo STF, no período de 1990 até 2003.

\section{Processos de extradição julgados pelo STF}

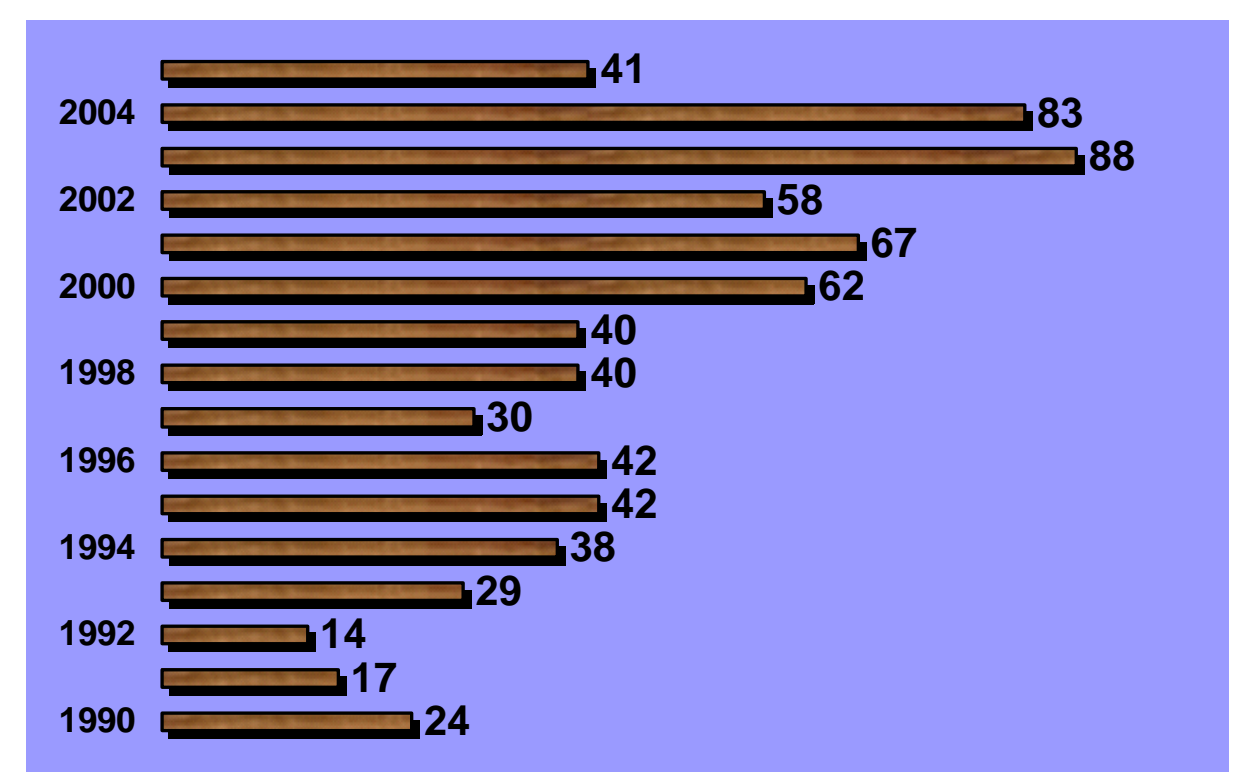

Fonte: http://www.stf.gov.br/bndpj/stf/ClasseProc.asp

Dados atualizados até 17/04/2005

As estatísticas demonstram que, depois da ação terrorista aos Estados Unidos, em 11 de setembro de 2000, os países têm buscado mais formas de cooperar para a manutenção da paz. A grande mobilização da comunidade internacional tem sido o combate ao terrorismo. Brant (2003, p. 3) afirma que algumas medidas precisam ser desenvolvidas, tais como:

a) observar os dispositivos do Estatuto de Roma do Tribunal Penal Internacional ${ }^{13}$ e possibilitar o desenvolvimento do direito internacional do terrorismo;

b) aperfeiçoar os mecanismos jurisdicionais da Corte Internacional de Justiça;

c) rediscutir o papel das Nações Unidas;

d) extinguir um dos principais fundamentos do discurso terrorista, mediante uma solução razoável e satisfatória para a questão palestina.

\footnotetext{
13 Assinado em Roma, em 17.07.1998. Foi aprovado no Brasil pelo Decreto Legislativo 112, de 06.06.2002, e promulgado pelo Decreto 4.388, de 25.09.2002. Depósito da Carta de Ratificação em 20.06.2002. Entrada em vigor internacional em 01.07.2002.
} 


\section{Conclusão}

A extradição é um dos procedimentos que os Estados utilizam para retirar um estrangeiro do seu território e tem como fundamento a cooperação entre os países que buscam, no âmbito internacional, a inibição do crime que, cada vez mais, tem-se especializado com o advento do processo de globalização. As ações terroristas têm-se disseminado pelo mundo e ultrapassado as fronteiras estatais.

A comunidade internacional utiliza-se do instituto da extradição para a manutenção da paz. No Brasil, o número dos processos de extradição julgados pelo Supremo Tribunal Federal tem aumentado a cada ano. As estatísticas demonstram que a extradição é um instrumento capaz de promover a repressão ao crime e punir os criminosos que migram para outras jurisdições, na tentativa de fugir da penalidade.

É importante salientar que os países devem buscar meios que permitam a repressão ao crime e a manutenção da paz. Para isso, é fundamental a utilização de instrumentos que promovam a cooperação entre os países.

\section{Referências}

ACCIOLY, Hildebrando. Manual de Direito Internacional Público. São Paulo: Saraiva, 1968.

ACQUARONE, Appio C. Tratados de extradição: construção, atualidade e projeção do relacionamento bilateral brasileiro. Brasília: Instituto Rio Branco - Alexandre Gusmão, 2003.

BRANT, Leonardo N. C. Terrorismo e direito - os impactos do terrorismo na comunidade internacional e no Brasil: perspectivas político-jurídicas. Rio de Janeiro: Forense, 2003.

CAHALI, Yussef Said. Estatuto do estrangeiro. São Paulo: Saraiva, 1983.

CALETTI, Cristina. Os precedentes do Tribunal Penal Internacional, seu estatuto e sua relação com a legislação brasileira . Jus Navigandi, Teresina, a. 7, n. 64, abr. 2003. Disponível em: <http://www1.jus.com.br/doutrina/texto.asp?id=3986>. Acesso em: 22 jul. 2004. 
CARNEIRO, Camila Tagliani. A extradição no ordenamento jurídico brasileiro. São Paulo: Memória Jurídica, 2002.

CAVARZERE, Thelma Thais. Direito internacional da pessoa humana: a circulação internacional de pessoas. 2 ed. Rio de Janeiro: Renovar, 2001.

DOLINGER, Jacob. Direito Internacional privado. 7 ed. Rio de Janeiro: Renovar, 2003.

ESTATÍSTICAS DO SÉCULO XX [recurso eletrônico]. Rio de Janeiro: IBGE, 2003.

FRAGA, Mirtô. O novo Estatuto do Estrangeiro comentado: Lei nº 6.815 de 1980, alterada pela lei $n^{\circ} 6.964$ de 1981. Rio de Janeiro: Forense, 1985.

MELLO, Celso D. de Albuquerque. Curso de direito internacional público. V. 2. 14 ed. Rio de Janeiro: Renovar, 2002.

MEIRA, Márcia de Brito. A extradição e o refúgio à luz do princípio da dignidade humana. In: MILESI, Rosita. Refugiados: realidade e perspectivas. Brasília: Loyola, 2003.

MIALHE, Jorge Luís. Imigração e dupla nacionalidade: aspectos históricos-jurídicos. In: BOUCAULT, C. E. de Abreu; MALATIAN, Teresa (coord). Políticas migratórias: fronteiras dos direitos humanos no século XXI. Rio de Janeiro: Renovar, 2003 , p. 209-232.

MILESI, Rosita. Migrantes e refugiados: proteção de seus direitos e resgate da dignidade humana. Disponível em: <http://www.migrante.org>. Acesso em: 01 maio 2004.

PAGDEN, Anthony. Povos e impérios: uma história de migrações e conquistas, da Grécia até a atualidade. Rio de Janeiro: Objetiva, 2002.

SUPREMO TRIBUNAL FEDERAL. Banco Nacional de Dados do Poder Judiciário BNDPJ: Processos Registrados, Distribuídos e Julgados por classe processual. . Disponível em: < http://www.stf.gov.br/bndpj/stf/ClasseProc.asp>. Acesso em 02 jul. 2004.

VELLOSO, Carlos Mário da Silva. A extradição e seu controle pelo Supremo Tribunal Federal. In: BRANT, Leonardo Nemer Caldeira. Terrorismo e direito - os impactos do terrorismo na comunidade internacional e no Brasil: perspectivas político-jurídicas. Rio de Janeiro: Forense, 2003.

VIEIRA, Oscar Vilhena. Supremo Tribunal Federal: jurisprudência política. São Paulo: Revista dos Tribunais, 1994. 